\title{
Epstein-Barr Virus-Associated Gastric Carcinoma: Use of Host Cell Machineries and Somatic Gene Mutations
}

\author{
Hiroyuki Abe $^{a}$ Atsushi Kanedab,c Masashi Fukayama $^{a, c}$ \\ ${ }^{a}$ Department of Pathology, Graduate School of Medicine, The University of Tokyo, Tokyo, ${ }^{b}$ Department of \\ Molecular Oncology, Graduate School of Medicine, Chiba University, Chiba, and ' ${ }^{C}$ CREST, Japan Science and \\ Technology Agency, Saitama, Japan
}

\section{Key Words}

Epstein-Barr virus - Gastric cancer - DNA methylation .

EBNA1 - Lymphoepithelioma-like carcinoma - microRNA .

Exosome $\cdot$ Molecular subtype $\cdot$ ARID1A $\cdot$ PIK3CA

\begin{abstract}
Epstein-Barr virus (EBV)-associated gastric carcinoma (EBVaGC) is a distinct subtype of gastric carcinoma, consisting of clonal growth of EBV-infected epithelial cells. Its unique characteristics have been demonstrated by epidemiological, clinical and pathological studies using in situ hybridization for EBV-encoded small RNAs. An oncogenic process for EBVaGC has also been revealed. EBV uses various host-cell machineries, including cell division machinery to propagate clonal virus genomes, DNA-methylation machinery to epigenetically control infected cells, and microRNA and exosome machineries to modify the behavior and microenvironment of infected cells. Recent comprehensive molecular analyses from The Cancer Genome Atlas project demonstrate that EBVaGC is a representative molecular subtype that is distinct from microsatellite unstable, genomically stable and chromosome unstable subtypes. In addition to having the highest level of DNA methylation in CpG islands of promoter regions, EBVaGC harbors particular gene altera-
\end{abstract}

tions, including a high frequency of mutations in PIK3CA and $A R I D 1 A$, mutation in $B C O R$, and amplification of $P D-L 1$ and $P D-L 2$. Although currently undetermined, the virus might use the altered cellular functions that are induced by these somatic mutations. Further investigation of virus-driven oncogenesis will enable hitherto unknown functions of stomach epithelial cell machineries to be elucidated, which may reveal potential therapeutic targets for EBVaGC.

두 2015 S. Karger AG, Base

\section{Introduction}

Gastric cancer is classified into several molecular subtypes. Epstein-Barr virus (EBV)-associated gastric carcinoma (EBVaGC) is a gastric carcinoma subtype resulting from clonal growth of EBV-infected stomach epithelial cells. This subtype has been considered as unique in its histopathological [1] and epigenetic features [2, 3], and, more recently, comprehensive molecular studies demonstrated EBVaGC to have characteristic molecular abnormalities $[4,5]$. This review first summarizes the epidemiological, clinical and pathological characteristics of EBVaGC. We then discuss the molecular basis of EBVinduced carcinogenesis, focusing on how the virus uses

\section{KARGER 125}

(c) 2015 S. Karger AG, Base

$1015-2008 / 15 / 0825-0212 \$ 39.50 / 0$

E-Mail karger@karger.com

www.karger.com/pat
Masashi Fukayama

Department of Pathology, Graduate School of Medicine

The University of Tokyo

Hongo 7-3-1, Tokyo 113-0033 (Japan)

E-Mail mfukayama-tky@umin.net 
Table 1. Characteristics of EBV-associated gastric carcinoma

\begin{tabular}{|c|c|}
\hline $\begin{array}{l}\text { Epidemi- } \\
\text { ology }\end{array}$ & $\begin{array}{l}\text { Worldwide distribution with no endemic area } \\
\text { Male predominance } \\
\text { H. pylori infection and smoking as a risk factor } \\
\text { Atrophic gastritis in the background mucosa } \\
\text { Lower mortality rate }\end{array}$ \\
\hline Pathology & $\begin{array}{l}\text { High frequency in the proximal stomach } \\
\text { Lower rate of lymph node metastasis } \\
\text { Histology of lymphoepithelioma-like carcinoma } \\
\text { or lace pattern } \\
\text { Infiltration of CD8-positive cytotoxic T cells }\end{array}$ \\
\hline $\begin{array}{l}\text { Molecular } \\
\text { biology }\end{array}$ & $\begin{array}{l}\text { Monoclonal viral genome in each tumor cell } \\
\text { DNA hypermethylation of viral and host genome } \\
\text { - Viral gene expression: latency I or II (EBNA1, } \\
\text { EBERs, LMP-2A, BARTs and BART miRNAs) } \\
\text { - Repression of tumor suppressor genes } \\
\text { (e.g. } p 14, p 16 \text { and } E \text {-cadherin) } \\
\text { Alteration of host miRNA expression } \\
\text { (e.g. suppression of miR-200) } \\
\text { Characteristic alterations of the host genome } \\
\text { - Frequent mutation of PIK3CA, ARID1A and } \\
\text { BCOR } \\
-\quad \text { Rare mutation of TP53 } \\
-\quad \text { Frequent amplification of PD-L1 and PD-L2 }\end{array}$ \\
\hline
\end{tabular}

host-cell machineries (virus strategy). We then highlight somatic gene mutations of host cells, which might be prerequisite or accelerating factors for virus-driven oncogenesis in the stomach. This review only briefly mentions viral latent gene products; therefore, we refer readers to a more comprehensive review of this area [6]. As an overview of this review, table 1 summarizes the characteristics of EBVaGC.

\section{Epidemiological, Clinical, and Pathological Features of EBVaGC}

EBVaGC is defined as clonal growth of EBV-infected stomach epithelial cells. Practically, EBVaGC can be identified by in situ hybridization (ISH) of EBV-encoded small RNAs (EBER1/EBER2) on formalin-fixed paraffinembedded sections of gastric carcinomas [7]. This is based on the fact that EBERs are abundantly produced in the nucleus of latently infected cells $\left(10^{6-7}\right.$ copies per cell); nearly all cancer cells are positive for EBER-ISH, while adjacent nonneoplastic gastric epithelial cells and infiltrating lymphocytes are negative [8]. Thus, positive nuclear signals for EBER-ISH are regarded as the gold standard for defining EBVaGC.

EBV-Associated Gastric Carcinoma

\section{Epidemiology}

The frequency of EBV infection in gastric carcinoma ranges from 2 to 20\%, with an average of 10\% [9]. EBVaGC is distributed worldwide with no endemic regions, although regional occurrence is well known in EBV-positive neoplasms, such as endemic Burkitt's lymphoma in Africa and New Guinea, and nasopharyngeal carcinoma in China and Southeast Asia $[10,11]$. Based on the Global Burden of Disease 2010 datasets, annual worldwide deaths from EBV-attributed malignancies are estimated at 69,081 cases of gastric carcinoma (EBVaGC), 63,118 cases of nasopharyngeal carcinoma, 7,917 cases of Hodgkin's lymphoma and 2,251 cases of Burkitt's lymphoma [12].

\section{Clinical Features}

According to a meta-analysis [13], the clinical features of EBVaGC include a predominance among male individuals and a predominant location in the proximal and middle regions of the stomach and in the remaining stomach after partial gastrectomy for gastric ulcer or gastric carcinoma (35.1\% of total remnant stomach cancers; 95\% CI 24.5-50.2\%). Camargo et al. [14] recently reported that smoking is a risk factor for EBVaGC (odds ratio of 1.5; 95\% CI 1.01-2.3). The frequency of Helicobacter pylori infection is controversial; some reports indicate less frequent $H$. pylori infection in $\operatorname{EBVaGC}[15,16]$, while others indicate that the infection frequency is higher in EBVaGC than in other gastric cancers $[17,18]$. However, the background mucosa in EBVaGC is characterized by severe atrophic gastritis with a paucity of intestinal metaplasia $[17,19]$.

The prognostic impact of EBV infection on gastric carcinoma is controversial. However, a recent meta-analysis of 4,599 gastric carcinoma cases (the largest to date), demonstrated that EBV positivity is associated with a reduced mortality rate after adjusting for the stage and other possible confounds (hazards ratio of 0.72 ; $95 \%$ CI $0.61-$ 0.86) [20].

\section{Pathological Characteristics}

Although the predominant site of gastric carcinoma is the antrum, EBVaGC frequently occurs in the upper and middle portion of the stomach. According to our previous study, EBVaGC is located in the cardia (58\%), body (33\%) and antrum (9\%) [21]. The gross appearance of EBVaGC is usually ulcerated or saucer-like, and the gastric wall is markedly thickened [7]. These characteristics can also be recognized by computerized tomography scanning [22]. EBV positivity does not correlate with the invasion depth 
$[9,23]$, which is compatible with the assumption that EBV plays an essential role in the development of the carcinoma. Some studies demonstrated that the rate of lymph node metastasis was lower in EBVaGC than other subtypes of gastric cancer [24,25], especially at the T1 stage. Synchronous multiple gastric carcinomas are frequently observed in patients with EBVaGC $[26,27]$.

There are two EBVaGC histological types, lymphoepithelioma-like carcinoma, LELC, which is also known as gastric carcinoma with lymphoid stroma, GCLS (fig. 1), and conventional-type adenocarcinoma [28], although there is a morphological continuum between these types. Morphologically, most LELCs or GCLSs are EBVaGC [13]. Another feature of EBVaGC, especially in its early stage, is a 'lace pattern' [29], which shows irregularly anastomosing tubules and cords associated with moderate-to-dense lymphocytic infiltration and results in a lace-like or reticular pattern at low magnification.

With regard to cell differentiation, EBVaGC displays unique features; nearly half of cases are positive for gastric-type mucin (MUC5AC and MUC6), while the other half are negative for gastric-type mucin or intestinal-type markers (MUC2 and CD10). Most EBVaGCs express gastric-type claudin, CLDN18, but not the intestinal type, CLDN3 [30, 31].

Infiltrating lymphocytes in EBVaGC are predominantly CD8-positive cytotoxic T cells [32] and at least partially contribute to antitumor immunity [33, 34]; however, the mechanism by which carcinoma cells evade the host immune response during tumor development and progression has not been determined. IL- $1 \beta$ is upregulated in mouse xenografts of human EBVaGC (KT tumor [35]) and in surgical specimens of EBVaGC. IL-1 $\beta$ might recruit numerous nonspecific lymphocytes to prevent direct contact between EBV-specific cytotoxic T cells and tumor cells [36]. In addition, major histocompatibility complex genes and the genes that regulate chemokine activity are more frequently deregulated in EBVaGC tissues relative to nontumor tissues [37].

\section{Virus-Driven Oncogenesis}

Before reviewing viral strategies to survive in the stomach mucosa, we should mention the initial step of 'EBV infection of epithelial cells', the mechanism of which remains largely unknown. The mechanism of EBV epithelial cell infection is different from that in B lymphocytes: gastric epithelial cells lack expression of major histocompatibility complex class II and CD21, which work as re- ceptors for EBV particles to enter B lymphocytes [38]. While viral protein gp42 interacts with major histocompatibility complex class II in B lymphocytes, another viral protein, $\mathrm{gHgL}$, forms a complex with human $\alpha \mathrm{v} \beta 5, \alpha v \beta 6$ or $\alpha v \beta 8$ integrin, which triggers fusion between the viral particle and host epithelial cell [39]. Viral glycoprotein BMRF-2 also interacts with cellular integrin and mediates infection [40]. EBV infection of gastric carcinoma cell lines can be established with an approximately 800 -foldhigher efficiency by cell-to-cell contact using the EBVpositive lymphocyte cell line, Akata, compared with direct incubation with viral particles [41]. Furthermore, a virus released from $B$ cells is 5 -fold more infectious for epithelial cells than B cells [39]. It is possible that EBV is transferred from EBV-infected B lymphocytes to gastric epithelial cells when the virus is reactivated (from latent to replicative infection) in B lymphocytes at the stomach mucosa. EBER-positive epithelial cells are rarely observed on the surface of gastric mucosa, suggesting that most infection is abortive [42]. However, once epithelial cell infection is established, the virus adopts the mechanisms described below for its survival (fig. 2).

\section{Virus Strategy 1}

Clonal EBV-DNA Is Maintained in EBVaGC

DNA in EBV viral particles is double stranded and linear, and becomes circular and episomal within infected cells. Varying numbers of terminal repeats (TRs) are excised from both ends of EBV DNA at the fusion of the linear DNA and, therefore, the number of TRs is different in each infected cell. Southern blot analysis of EBV-TRs, when applied to EBVaGC, demonstrates that EBV is monoclonal in each carcinoma of advanced stages [42, 43], and monoclonal or oligo-clonal even in its intramucosal stage [44]. The clonality of the viral genome suggests that the infection of EBV is an early event of carcinogenesis of EBVaGC. Although there has been no study which disclosed the significance of oligo-clonal infection of EBV in the early stage, it is possible that one of the clones becomes invasive and progresses to the advanced stage, resulting in the monoclonality. Southern blot analysis also shows that the EBV DNA copy number per cell is variable in each case of EBVaGC, from several copies to more than 100 [42]. Although the viral genome is sometimes integrated into the host genome instead of forming episomes in lymphoma or nasopharyngeal carcinoma with EBV infection [45], integration of the viral genome has not been reported in EBVaGC. Analysis of 71 cases of gastric carcinoma in The Cancer Genome Atlas (TCGA) database detected EBV transcripts in 4 cases but found no evidence 

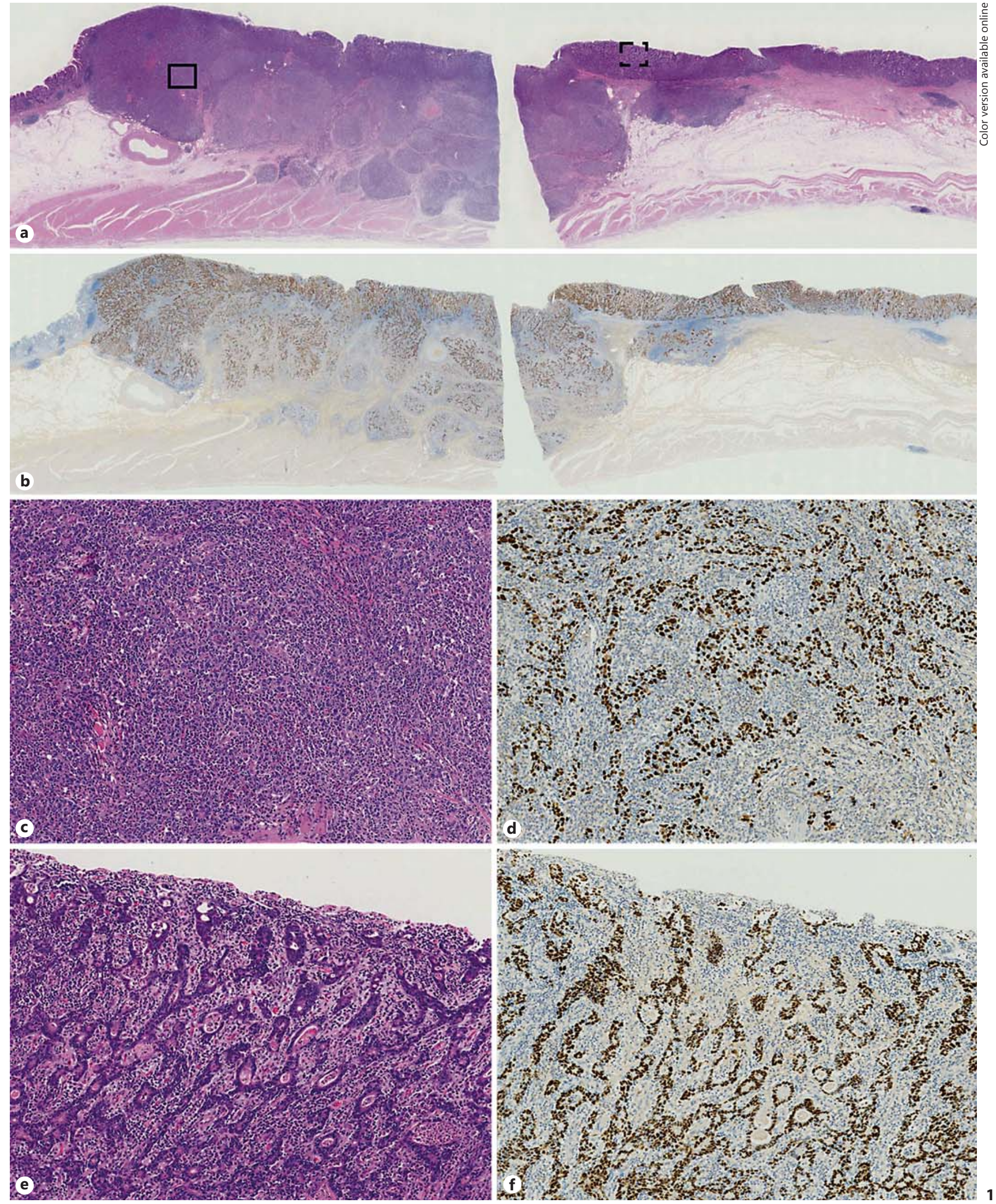

(For legend see next page.) 
of viral genome integration into the host genome [46]. Another study of whole-genome sequencing including 4 cases of EBVaGC also identified no chromosomal integration of the viral genome [47].

The earliest events in the development of EBVaGC have not yet been clarified, but one or several infected cells in the stomach mucosa containing original copies of EBV DNA ultimately transform to start clonal growth. Viral nuclear protein, EBNA1, is a multifunctional protein that is necessary for maintaining viral infection in host cells by contributing to replication and mitotic segregation of the viral genome. EBNA1 recruits a cellular origin-recognition complex, which is necessary for DNA replication, to OriP of the viral DNA. Using the cellular machinery, viral replication is initiated during the host cell $S$ phase. In addition, EBNA1 tethers viral episomes to the host chromosomes, which enables propagation of the same copy number of viral genomes to the daughter cells at mitosis [48].

\section{Virus Strategy 2}

Epigenetic Silencing of Viral Genes and Host Genes

Epigenetic regulation of both viral and host genes is important in EBV-associated neoplasms. Histone modifications and chromatin organization are just beginning to be investigated [49]; therefore, we will focus on DNA methylation in this review, which has been relatively well studied. The viral DNA, including transcription initiation sites for lytic genes, is densely methylated in latently infected cells [50]. When viral immediate early protein and transcription factor Zta (ZEBRA, Z, BZLF1) is expressed in response to reactivation agents, it selectively binds to methylated DNA of viral lytic promotors, causing the infected cell to transit from latency to lytic infection [51]. Latent EBV infection is classified into three forms by the expression patterns of latent genes. EBER-1 and 2, EBV-determined nuclear antigen (EBNA)-1, Bam-

Fig. 1. Hematoxylin and eosin staining and EBER-ISH of EBVaGC: low-power view $(\mathbf{a}, \mathbf{b})$ and high-power view $(\mathbf{c}, \mathbf{d})$ of the invasive area (solid square in $\mathbf{a}$ ); high-power view $(\mathbf{e}, \mathbf{f})$ of the intramucosal area (dashed square in a). EBVaGC is a highly cellular lesion because of dense lymphocytic infiltration $(\mathbf{a}, \mathbf{c}, \mathbf{e})$. EBER-ISH reveals EBV infection in nearly all tumor cells, but not in infiltrating lymphocytes $(\mathbf{b}, \mathbf{d}, \mathbf{f})$. The high-power view reveals poorly differentiated carcinoma with prominent lymphocytic infiltration (lymphoepithelioma-like carcinoma), which is a characteristic histology of $\mathrm{EBVaGC}(\mathbf{c}, \mathbf{d})$. In intramucosal lesions, a 'lace pattern' is noted. Small glands of tumor cells are interconnected with each other (e, f). a, c, e Hematoxylin and eosin stain. b, d, f EBER-ISH.
$\mathrm{HI}-\mathrm{A}$ region rightward transcripts (BARTs), and BART microRNAs (miRNAs; discussed later) are expressed in all latency types. In latency type II, latent membrane protein (LMP)-1, 2A or 2B are also expressed, and latency type III includes all of these latent genes along with EBNA-2, 3A, 3B, 3C and LP. EBVaGC belongs to latency type I or II, in which EBERs, EBNA-1, BARTs and BART miRNAs are expressed, and approximately half of EBVaGC cases express LMP-2A. In determining the latency, $\mathrm{CpG}$ methylation of latent gene promotors also plays a central role, although it is not known how different methylation patterns are established [1].

It is surprising that DNA methylation also occurs at high frequencies in $\mathrm{CpG}$ islands of the promotor region of host genes in EBVaGC [52]. Various tumor suppressor genes, such as $p 14, p 16$ and E-cadherin, are suppressed through promoter methylation in EBVaGC [53-55]. Furthermore, this process is not random; for example, $M L H 1$, which is methylated in microsatellite unstable gastric carcinoma, is not methylated in EBVaGC $[56,57]$. Recently,

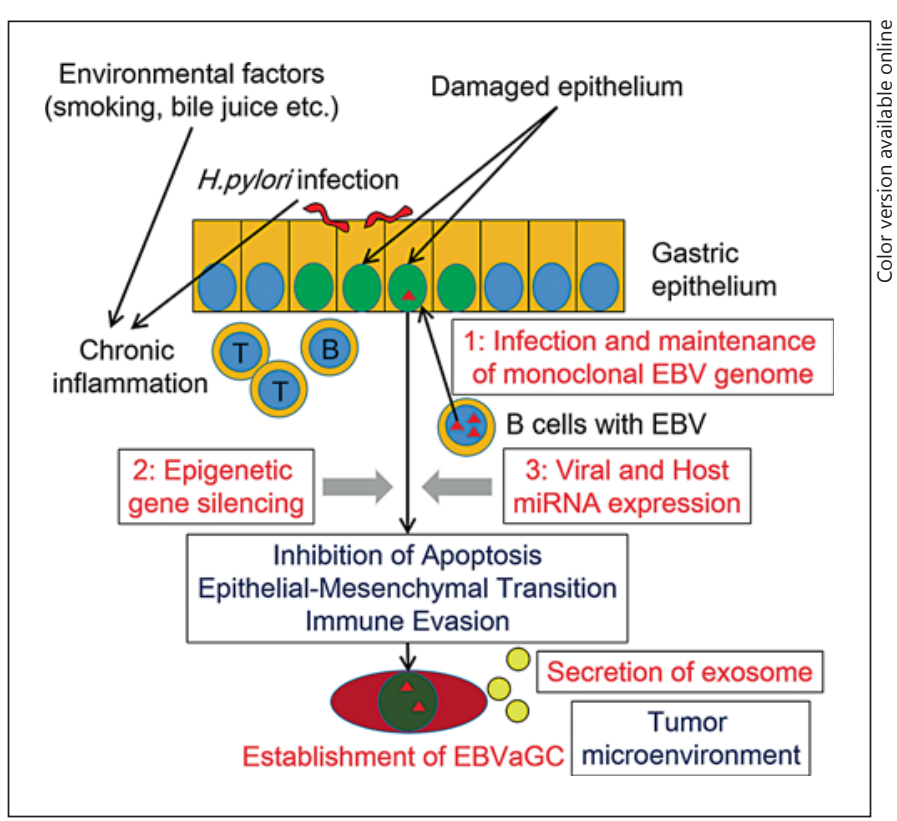

Fig. 2. Schematic of viral oncogenesis in EBVaGC. Chronic inflammation induced by environmental factors and $H$. pylori infection results in background mucosa with infiltration of lymphocytes including EBV-infected B cells. The stomach epithelial cells can be infected from reactivated EBV-infected B cells. Once latent infection is established, EBV uses cellular machineries for maintenance of the viral genome in host cells, DNA hypermethylation of viral and host genomes, alteration of miRNA expression, and secretion of exosomes, resulting in the development and progression of EBVaGC. 
we performed a genome-wide comprehensive methylation analysis of gastric carcinoma, and identified three distinct epigenotypes (EBV-/low methylation, EBV-/ high methylation, and EBV+/high methylation). In $\mathrm{EBV}+/$ high methylation gastric carcinoma, genes methylated in EBV-/high methylation gastric carcinoma and EBVaGC-specific genes are both extensively methylated. However, genes methylated in EBV-/high methylation gastric carcinoma were mainly the target of a polycomb recessive complex, while genes methylated specifically in EBVaGC were not. These observations suggest a unique or additional mechanism of DNA methylation in EBVaGC. Furthermore, using MKN7, a gastric cancer cell line with low methylation, we showed that global methylation was induced in EBVaGC-specific genes and in genes methylated in the EBV-/high methylation epigenotype by EBV infection $[2,3]$. Interestingly, a study using oral keratinocytes revealed that DNA methylation of the host genome was induced by EBV infection and that some methylation was retained even after the virus was lost from the infected cells [58].

The exact mechanisms of EBV-driven hypermethylation, described above, remain unknown. We observed that the viral latent protein LMP2A induced 5-fold overexpression of DNMT1 through phosphorylation of STAT3, leading to methylation of the PTEN promotor in infected gastric cancer cell lines, although this pathway could only partially explain the global CpG-island methylation of EBVaGC [59]. Nevertheless, using an experimental EBV infection system, viral DNA methylation was shown to precede the methylation of host DNA by 1 week [Matsusaka et al., in preparation]. Therefore, the methylation of viral genes might be caused by a host defense mechanism against foreign DNA to suppress the expression of viral genes. However, this might result in other outcomes - repressing viral latent gene expression might benefit EBV by allowing it to evade a host's immune response [60]. Excessive methylation also leads to the repression of tumor suppressor genes, as described above, which promotes the survival of infected cells.

\section{Virus Strategy 3}

Viral and Host microRNAs

miRNAs are small noncoding RNA molecules $\sim 22$ nucleotides in length encoded in the introns or exons of genes. miRNA precursors are processed from these transcripts and subsequently processed by Drosha and Dicer into mature forms. Mature miRNAs interact with the $3^{\prime}$-untranslated regions of target mRNAs and repress their translation [61]. EBV also encodes its own
miRNAs in its genome. There are 25 miRNA precursors and 44 mature EBV miRNAs in EBV. Three of the miRNA precursors are derived from the BHRF1 cluster and the remaining 22 are from the BART cluster. BHRF1 expression is restricted to latency III, and only BART miRNAs are expressed in EBVaGC, or in other EBVassociated neoplasms of latency I and II [62-64]. We recently profiled the expression of the 44 known EBV miRNAs in tissue samples from patients with EBVaGC; ebv-miR-BART1-3p, 2-5p, 3, 4, 5, 7, 9, 10-3p, 17-5p, and $18-5 p$ were expressed at relatively high levels. In silico analysis revealed that the target genes of these EBV miRNAs had functions associated with cancer-related pathways, especially the regulation of apoptosis. Apoptosis was in fact reduced in tissue samples of EBVaGC, and the gastric carcinoma cell lines infected with EBV exhibited downregulation of the proapoptotic protein Bid (the BH3-interacting domain death agonist), a member of the Bcl-2 family. Subsequent experiments demonstrated that ebv-miR-BART4-5p regulates Bid expression in EBVaGC [65]. Cai et al. [66] recently demonstrated in nasopharyngeal carcinoma that ebv-miRBART7-3p, one of the most abundant viral miRNAs in EBVaGC, targets the tumor suppressor gene PTEN, and promotes epithelial-to-mesenchymal transition and tumor metastasis.

Human cellular miRNA expression profiles are also altered by EBV infection. We previously reported that two cellular miRNAs, hsa-miR-200a and hsa-miR-200b, were downregulated in EBVaGC, both in tissue samples and cell lines. These miRNAs target the transcription repressors ZEB1 and ZEB2, which regulate E-cadherin expression. Downregulation of these miRNAs ultimately reduced E-cadherin expression and triggered epithelialto-mesenchymal transition. The EBV latent genes BARF0, EBNA-1 and EBERs cooperatively suppressed hsa-miR200a and 200b expression in cell lines, while reduced ZEB1, ZEB2 and E-cadherin expression was significant only in EBER-transfected cells [67]. EBV infection causes a decrease in the levels of tumor suppressor miRNAs (antioncomirs) such as the let-7 family [64].

The role of miRNAs is not only intracellular regulation of gene expression, but also intercellular communication and modification of the tumor microenvironment [68]. Exosomes, small vesicles with lipid bilayer membranes, are derived from endoplasmic multivesicular bodies and carry proteins and RNAs from cell to cell. Pegtel et al. [69] demonstrated that miRNAs secreted by EBV-infected cells are transferred to and act in uninfected recipient cells. They showed by coculture of EBV-infected B cells 
that EBV-miRNAs accumulated in noninfected, neighboring monocyte-derived dendritic cells - MoDCs through exosome transfer. The miRNAs, internalized in MoDCs, then downregulated their target molecules [70]. The significance of secreted miRNAs in EBVaGC is not clear at present, but some studies suggest functions of exosomes, which are derived from EBV-negative gastric cancer. For example, exosomes derived from gastric cancer cell lines induced mesenchymal stem cells to differentiate into carcinoma-associated fibroblasts [71], and induced apoptosis in Jurkat T cells [72]. Thus, it is possible that viral miRNAs in exosomes also play an important role in modulating the tumor microenvironment in EBVaGC. Furthermore, exosomal miRNAs are relatively stable in circulating blood and have been identified in the circulating blood of nasopharyngeal carcinoma patients. They may be useful as biomarkers of the diagnosis of EBVaGC [73-75].

\section{Molecular Abnormalities Demonstrated by 'Omics' Studies}

The TCGA Research Network recently reported the results of a comprehensive molecular evaluation of 295 gastric carcinomas according to several different modalities, such as genomic alterations, gene expression profiling and proteomic analysis. They proposed a novel molecular classification which divides gastric carcinomas into four types: $\mathrm{EBVaGC}$, microsatellite unstable tumors, genomically stable tumors and tumors with chromosomal instability. The study confirmed characteristic hypermethylation of DNA, and further identified recurrent mutations of ARID1A (55\%) and PIK3CA (80\%) in EBVaGC. Other frequent mutations included $B C O R$ (23\%), but TP53 mutation was extremely rare. Chromosomal abnormality is not common in EBVaGC, but amplification of $J A K 2, P D-L 1$ and $P D-L 2$ were frequent in EBVaGC [5].

\section{ARID1A}

ARID1A is a subunit of the SWI/SNF chromatin remodeling complex and is thought to have a tumor suppression role by regulating chromatin structure and gene expression [76]. ARID1A is frequently mutated in microsatellite unstable gastric carcinoma as well as in EBVaGC $[77,78]$. Mutation of ARID1A was first reported in ovarian clear cell and endometrioid adenocarcinoma $[79,80]$. Subsequently, recurrent mutations of ARID1A have been reported in other carcinomas, such as colorectal [81], he- patocellular [82-85] and bladder carcinoma [86]. There are no hot spots for ARID1A mutations and most are missense or truncation mutations, which result in lost or weak expression of ARID1A protein [77, 79]. A high frequency of ARID1A mutation in microsatellite unstable gastric carcinoma can be explained by deficiency of the mismatch repair system because most of the mutations are indels, which is common in tumors with microsatellite instability $[77,87]$. However, it is unknown why mutation of ARID1A is more frequent in EBVaGC compared with other gastric carcinomas.

We investigated the loss of ARID1A expression by applying immunohistochemistry to a large series of gastric carcinoma tissue microarrays. Loss of ARID1A was frequently observed in EBVaGC and MLH1-negative gastric carcinoma (corresponding to the microsatellite unstable type [88-90], as described above). Characteristic to EBVaGC is homogeneous loss of ARID1A within the tumor (all-or-none-type expression) independent of the invasion depth, indicating that loss of ARID1A is an early event in EBVaGC carcinogenesis [21]. According to a deep sequencing study of nonneoplastic gastric mucosa [91], ARID1A mutations were present in chronically inflamed and $H$. pylori-infected gastric mucosa, although the copy number of the mutated gene was low. These observations suggest that the mutation event precedes EBV infection. Mutations in ARID1A, leading to altered chromatin structures, might facilitate viral entry to the nucleus or manipulation of methylation mechanisms $[92,93]$.

\section{PIK3CA}

PIK3CA is an important regulator of the PI3K/Akt pathway. Mutations in PIK3CA are frequent in cancers of various organs, such as colon, breast, endometrium and ovary. These mutations are mostly hot-spot mutations located in exon 9 (E542K and E545K) and exon 20 (H1047R) $[94,95]$. It is of interest that the mutation sites in PIK3CA are distributed widely in EBVaGC [5] with only $28 \%$ of mutations in hot spots. A considerable number of these non-hot-spot mutants, however, show moderate-toweak transformation activity and/or lipid phosphorylation activity [96]. Similarly to ARID1A mutation, it is possible that PIK3CA mutation precedes EBV infection, which then augments functions of mutated PIK3CA to activate the PI3K/Akt pathway. The viral protein LMP2A is known to upregulate PI3K/Akt pathways [97], and EBV-induced DNA methylation of PTEN and INPP4B (inhibitors of the pathway) could contribute to this process $[59,98]$. The PI3K/Akt pathway is involved in many 
biological processes [97]; therefore, the significance of its activation through non-hot-spot mutations in early carcinogenesis of EBVaGC is far from clear. However, EBV infection in immortalized nasopharyngeal epithelial cells showed sustained activation of pAkt under nutrient deficiency, which contributed to their survival [99]. Furthermore, the coexistence of ARID1A and PIK3CA mutations is frequently observed in ovarian clear cell carcinoma and in some foci of endometriosis, especially atypical endometriosis [100, 101]. Chandler et al. [102] recently demonstrated that both mutations cooperate to promote tumor growth through sustained IL-6 overproduction in the ovarian surface epithelium of a mutant mouse model of ovarian clear cell carcinoma. Therefore, further studies are necessary to clarify how EBV uses the consequences of these mutations in EBVaGC.

The hypothetical crosstalk between EBV and PIK3CA mutations, however, should be cautiously considered. According to other sequencing studies of gastric carcinoma, the frequencies of PIK3CA mutation vary considerably in EBVaGC $[4,77,103,104]$. The variable frequencies might be due to the tumor content or the methods used in the studies.

\section{$B C O R$}

The Bcl-6 corepressor antiapoptotic protein $B C O R$ [105] is frequently mutated in acute leukemia $[106,107]$ and medulloblastoma [108]. Tiberi et al. [109] recently demonstrated that BCL6 represses GLI1 and GLI2, effectors of the SHH pathway, through recruitment of BCOR and SIRT1 deacetylase. Because the targets of the BCL6/ BCOR/SIRT1 complex depend on the cellular context, further studies are necessary to clarify the significance of this mutation in EBVaGC.

\section{Amplification of PD-L1 and PD-L2}

As mentioned previously, comprehensive analysis of gastric carcinoma revealed amplification of $P D-L 1$ and $P D-L 2$ in EBVaGC [5]. The finding is very interesting because these genes are thought to play a role in evasion from tumor immunity. Both PD-L1 and PD-L2 are ligands of PD-1 (programmed death-1), which is a coreceptor of mature CD4+ and CD8+ T cells, and activation of the PD-1 pathway induces immune tolerance [110]. Overexpression of $\mathrm{PD}-\mathrm{L} 1$ and subsequent evasion from tumor immunity is a known process for cancer progression, and carcinomas with PD-L1 expression are more aggressive and associated with a worse prognosis in renal cell carcinoma [111]. Gastric carcinoma with PD-L1 expression is also associated with an advanced tumor stage

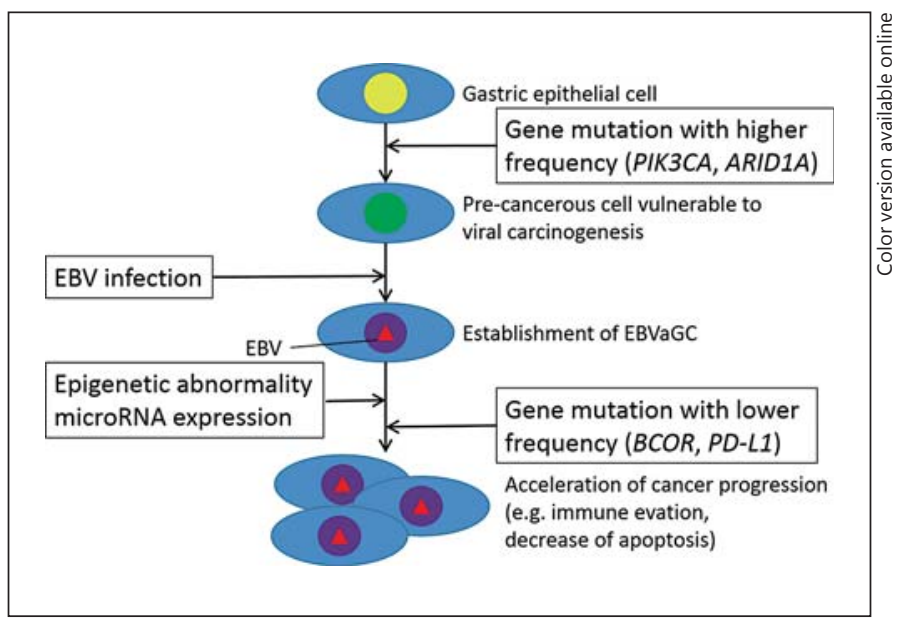

Fig. 3. Hypothesis regarding the coordination of EBV and somatic gene mutation in EBVaGC. Somatic mutations in PIK3CA and ARID1A (which have a high frequency in EBVaGC) might promote viral infection and the establishment of EBV-infected epithelial cells. Mutation in $B C O R$ and amplification of $P D-L 1$ (which have a lower frequency in EBVaGC) might accelerate cancer progression through the inhibition of apoptosis and evasion of tumor immunity.

and worse prognosis $[112,113]$. Because EBVaGC has markedly dense CD8-positive lymphocytic infiltration in the tumor cell nest and tumor stroma [32], escape from the $\mathrm{T}$ cell immune system is essential for tumor progression. Blockade of the PD-L1/PD-1 pathway with anti-PDL1 antibody showed an anticancer effect in some clinical trials [114-116]. Therapy targeting PD-L1 might also be effective in EBVaGC, and further study of PD-L1 in EBVaGC is necessary.

\section{Conclusions}

EBVaGC is a distinct gastric carcinoma, not only in its unique epidemiological, clinical and histological characteristics, but also in its molecular mechanisms. Viruses use cellular machineries for their survival, for example to propagate the monoclonal viral genome, to epigenetically silence viral and host genes, and to control the infected cell's behavior and microenvironment. In addition, recent comprehensive molecular analyses ('-omics' studies) have demonstrated frequent alterations of the host genome (frequent mutation of PIK3CA, ARID1A and $B C O R$, and amplification of $P D-L 1$ and $P D-L 2)$. Highfrequency mutations, such as in PIK3CA and ARID1A, might be a prerequisite for the development of EBVaGC. 
In EBV-positive Burkitt's lymphoma, EBV is considered to rescue B cells with Ig-myc translocation, which are otherwise excluded by apoptosis [117]. Lower-frequency mutations, such as in $B C O R$ or amplification of $P D-L 1$ and $P D-L 2$, might contribute to cancer progression and immune evasion (fig. 3). Further studies are necessary to clarify this coordination of virus and host cell mutations to enable targeting of therapeutic candidates against this particular subtype of gastric carcinoma.

\section{Acknowledgments}

This work was supported by Grants-in-Aid for Scientific Research (KAKENHI) from the Japan Society for the Promotion of Science (JSPS; Grant No. 26860232 to H.A. and 26253021 to M.F.), and from the Core Research for Evolutionary Science and Technology (CREST) program from the Japan Science and Technology Agency to A.K. and M.F.

\section{References}

1 Fukayama M, Ushiku T: Epstein-Barr virusassociated gastric carcinoma. Pathol Res Pract 2011;207:529-537.

-2 Matsusaka K, Kaneda A, Nagae G, Ushiku T, Kikuchi Y, Hino R, Uozaki H, Seto Y, Takada K, Aburatani H, Fukayama M: Classification of Epstein-Barr virus-positive gastric cancers by definition of DNA methylation epigenotypes. Cancer Res 2011;71:7187-7197.

3 Kaneda A, Matsusaka K, Aburatani H, Fukayama M: Epstein-Barr virus infection as an epigenetic driver of tumorigenesis. Cancer Res 2012;72:3445-3450.

4 Wang K, Yuen ST, Xu J, Lee SP, Yan HH, Shi ST, Siu HC, Deng S, Chu KM, Law S, Chan $\mathrm{KH}$, Chan AS, Tsui WY, Ho SL, Chan AK, Man JL, Foglizzo V, Ng MK, Chan AS, Ching YP, Cheng GH, Xie T, Fernandez J, Li VS, Clevers H, Rejto PA, Mao M, Leung SY: Wholegenome sequencing and comprehensive molecular profiling identify new driver mutations in gastric cancer. Nat Genet 2014;46: 573-582.

$\checkmark 5$ Network CGAR: Comprehensive molecular characterization of gastric adenocarcinoma. Nature 2014;513:202-209.

6 Shinozaki-Ushiku A, Kunita A, Fukayama M: Update on Epstein-Barr virus and gastric cancer (review). Int J Oncol 2015;46:1421-1434.

$>7$ Fukayama M: Epstein-Barr virus and gastric carcinoma. Pathol Int 2010;60:337-350.

$>8$ Tokunaga M, Land CE, Uemura Y, Tokudome T, Tanaka S, Sato E: Epstein-Barr virus in gastric carcinoma. Am J Pathol 1993;143: 1250-1254.

$>9$ Camargo MC, Murphy G, Koriyama C, Pfeiffer RM, Kim WH, Herrera-Goepfert R, Corvalan AH, Carrascal E, Abdirad A, Anwar M, Hao Z, Kattoor J, Yoshiwara-Wakabayashi E, Eizuru Y, Rabkin CS, Akiba S: Determinants of Epstein-Barr virus-positive gastric cancer: an international pooled analysis. $\mathrm{Br} \mathrm{J}$ Cancer 2011;105:38-43.

10 Iizasa H, Nanbo A, Nishikawa J, Jinushi M, Yoshiyama H: Epstein-Barr virus (EBV)-associated gastric carcinoma. Viruses 2012;4: 3420-3439.

$>11$ Young LS, Rickinson AB: Epstein-Barr virus: 40 years on. Nat Rev Cancer 2004;4:757-768.
12 Khan G, Hashim MJ: Global burden of deaths from Epstein-Barr virus attributable malignancies 1990-2010. Infect Agent Cancer 2014;9:38.

13 Murphy G, Pfeiffer R, Camargo MC, Rabkin CS: Meta-analysis shows that prevalence of Epstein-Barr virus-positive gastric cancer differs based on sex and anatomic location. Gastroenterology 2009;137:824-833.

14 Camargo MC, Koriyama C, Matsuo K, Kim WH, Herrera-Goepfert R, Liao LM, Yu J, Carrasquilla G, Sung JJ, Alvarado-Cabrero I, Lissowska J, Meneses-Gonzalez F, Yatabe Y, Ding T, Hu N, Taylor PR, Morgan DR, Gulley ML, Torres J, Akiba S, Rabkin CS, Group E-E: Case-case comparison of smoking and alcohol risk associations with Epstein-Barr viruspositive gastric cancer. Int J Cancer 2014;134: 948-953.

15 Wu MS, Shun CT, Wu CC, Hsu TY, Lin MT, Chang MC, Wang HP, Lin JT: Epstein-Barr virus-associated gastric carcinomas: relation to $H$. pylori infection and genetic alterations. Gastroenterology 2000;118:1031-1038.

-16 Luo B, Wang Y, Wang XF, Gao Y, Huang BH, Zhao P: Correlation of Epstein-Barr virus and its encoded proteins with Helicobacter pylori and expression of c-met and c-myc in gastric carcinoma. World J Gastroenterol 2006;12: 1842-1848

17 Yanai H, Murakami T, Yoshiyama H, Takeuchi $\mathrm{H}$, Nishikawa J, Nakamura H, Okita K, Miura O, Shimizu N, Takada K: Epstein-Barr virus-associated gastric carcinoma and atrophic gastritis. J Clin Gastroenterol 1999;29: 39-43.

18 Lima VP, de Lima MA, Andre AR, Ferreira MV, Barros MA, Rabenhorst SH: H. pylori (CagA) and Epstein-Barr virus infection in gastric carcinomas: correlation with p53 mutation and c-myc, bcl-2 and bax expression. World J Gastroenterol 2008;14:884-891.

19 Kaizaki Y, Sakurai S, Chong JM, Fukayama M: Atrophic gastritis, Epstein-Barr virus infection, and Epstein-Barr virus-associated gastric carcinoma. Gastric Cancer 1999;2: 101-108.
20 Camargo MC, Kim WH, Chiaravalli AM, Kim KM, Corvalan AH, Matsuo K, Yu J, Sung JJ, Herrera-Goepfert R, Meneses-Gonzalez F, Kijima Y, Natsugoe S, Liao LM, Lissowska J, Kim S, Hu N, Gonzalez CA, Yatabe Y, Koriyama C, Hewitt SM, Akiba S, Gulley ML, Taylor PR, Rabkin CS: Improved survival of gastric cancer with tumour Epstein-Barr virus positivity: an international pooled analysis. Gut 2014;63:236-243.

21 Abe H, Maeda D, Hino R, Otake Y, Isogai M, Ushiku AS, Matsusaka K, Kunita A, Ushiku T, Uozaki H, Tateishi Y, Hishima T, Iwasaki Y, Ishikawa S, Fukayama M: ARID1A expression loss in gastric cancer: pathway-dependent roles with and without Epstein-Barr virus infection and microsatellite instability. Virchows Arch 2012;461:367-377.

22 Maeda E, Akahane M, Uozaki H, Kato N, Hayashi N, Fukayama M, Ohtomo K: CT appearance of Epstein-Barr virus-associated gastric carcinoma. Abdom Imaging 2009;34: 618-625.

23 Lee JH, Kim SH, Han SH, An JS, Lee ES, Kim YS: Clinicopathological and molecular characteristics of Epstein-Barr virus-associated gastric carcinoma: a meta-analysis. J Gastroenterol Hepatol 2009;24:354-365.

24 van Beek J, zur Hausen A, Klein Kranenbarg E, van de Velde CJ, Middeldorp JM, van den Brule AJ, Meijer CJ, Bloemena E: EBV-positive gastric adenocarcinomas: a distinct clinicopathologic entity with a low frequency of lymph node involvement. J Clin Oncol 2004; 22:664-670.

25 Ushiku T, Shinozaki A, Fukayama M: Epstein-Barr virus-associated gastric carcinoma. Stomach Intestine 2009;44:723-729.

26 Matsunou H, Konishi F, Hori H, Ikeda T, Sasaki K, Hirose Y, Yamamichi N: Characteristics of Epstein-Barr virus-associated gastric carcinoma with lymphoid stroma in Japan. Cancer 1996;77:1998-2004.

27 Chang MS, Lee HS, Kim HS, Kim SH, Choi SI, Lee BL, Kim CW, Kim YI, Yang M, Kim WH: Epstein-Barr virus and microsatellite instability in gastric carcinogenesis. J Pathol 2003; 199:447-452. 
$\checkmark 28$ Nakamura S, Ueki T, Yao T, Ueyama T, Tsuneyoshi M: Epstein-Barr virus in gastric carcinoma with lymphoid stroma: special reference to its detection by the polymerase chain reaction and in situ hybridization in 99 tumors, including a morphologic analysis. Cancer 1994;73:2239-2249.

-29 Arikawa J, Tokunaga M, Satoh E, Tanaka S, Land CE: Morphological characteristics of Epstein-Barr virus-related early gastric carcinoma: a case-control study. Pathol Int 1997; $47: 360-367$

-30 Nakamura Y, Yanai H, Kitou T, Matsubara Y, Hirano A, Okamoto T, Yoshida T, Okita K, Matsusaki K: Mucin and differentiation in Epstein-Barr virus-associated gastric carcinoma. Hepatogastroenterology 2005;52:10661070.

- 31 Shinozaki A, Ushiku T, Morikawa T, Hino R, Sakatani T, Uozaki H, Fukayama M: EpsteinBarr virus-associated gastric carcinoma: a distinct carcinoma of gastric phenotype by claudin expression profiling. J Histochem Cytochem 2009;57:775-785.

-32 Saiki Y, Ohtani H, Naito Y, Miyazawa M, Nagura $\mathrm{H}$ : Immunophenotypic characterization of Epstein-Barr virus-associated gastric carcinoma: massive infiltration by proliferating CD8+ T-lymphocytes. Lab Invest 1996;75: 67-76.

- 33 Song HJ, Srivastava A, Lee J, Kim YS, Kim KM, Ki Kang W, Kim M, Kim S, Park CK: Host inflammatory response predicts survival of patients with Epstein-Barr virus-associated gastric carcinoma. Gastroenterology 2010; 139:84-92.e82.

-34 Kuzushima K, Nakamura S, Nakamura T, Yamamura Y, Yokoyama N, Fujita M, Kiyono T, Tsurumi T: Increased frequency of antigenspecific $\mathrm{CD}^{+}$cytotoxic $\mathrm{T}$ lymphocytes infiltrating an Epstein-Barr virus-associated gastric carcinoma. J Clin Invest 1999;104:163171.

- 35 Iwasaki Y, Chong JM, Hayashi Y, Ikeno R, Arai K, Kitamura M, Koike M, Hirai K, Fukayama M: Establishment and characterization of a human Epstein-Barr virus-associated gastric carcinoma in SCID mice. J Virol 1998; 72:8321-8326.

36 Chong JM, Sakuma K, Sudo M, Osawa T, Ohara E, Uozaki H, Shibahara J, Kuroiwa K, Tominaga S, Hippo Y, Aburatani H, Funata $\mathrm{N}$, Fukayama M: Interleukin- $1 \beta$ expression in human gastric carcinoma with Epstein-Barr virus infection. J Virol 2002;76:6825-6831.

37 Kim SY, Park C, Kim HJ, Park J, Hwang J, Kim JI, Choi MG, Kim S, Kim KM, Kang MS: Deregulation of immune response genes in patients with Epstein-Barr virus-associated gastric cancer and outcomes. Gastroenterology 2015;148:137-147.e139.

- 38 Yoshiyama H, Imai S, Shimizu N, Takada K: Epstein-Barr virus infection of human gastric carcinoma cells: implication of the existence of a new virus receptor different from CD21. J Virol 1997;71:5688-5691.
9 Chesnokova LS, Hutt-Fletcher LM: EpsteinBarr virus infection mechanisms. Chin J Cancer 2014;33:545-548.

40 Tugizov SM, Berline JW, Palefsky JM: Epstein-Barr virus infection of polarized tongue and nasopharyngeal epithelial cells. Nat Med 2003;9:307-314.

41 Imai S, Nishikawa J, Takada K: Cell-to-cell contact as an efficient mode of Epstein-Barr virus infection of diverse human epithelial cells. J Virol 1998;72:4371-4378.

42 Fukayama M, Hayashi Y, Iwasaki Y, Chong J, Ooba T, Takizawa T, Koike M, Mizutani S, Miyaki M, Hirai K: Epstein-Barr virus-associated gastric carcinoma and Epstein-Barr virus infection of the stomach. Lab Invest 1994;71: 73-81.

43 Imai S, Koizumi S, Sugiura M, Tokunaga M, Uemura Y, Yamamoto N, Tanaka S, Sato E, Osato T: Gastric carcinoma: monoclonal epithelial malignant cells expressing EpsteinBarr virus latent infection protein. Proc Natl Acad Sci USA 1994;91:9131-9135.

44 Uozaki H, Fukayama M: Epstein-Barr virus and gastric carcinoma - viral carcinogenesis through epigenetic mechanisms. Int J Clin Exp Pathol 2008;1:198-216.

45 Morissette G, Flamand L: Herpesviruses and chromosomal integration. J Virol 2010;84: 12100-12109.

46 Khoury JD, Tannir NM, Williams MD, Chen Y, Yao H, Zhang J, Thompson EJ, MericBernstam F, Medeiros LJ, Weinstein JN, Su X: Landscape of DNA virus associations across human malignant cancers: analysis of 3,775 cases using RNA-Seq. J Virol 2013;87:89168926.

47 Wong SS, Kim KM, Ting JC, Yu K, Fu J, Liu S, Cristescu R, Nebozhyn M, Gong L, Yue YG, Wang J, Ronghua C, Loboda A, Hardwick J, Liu X, Dai H, Jin JG, Ye XS, Kang SY, Do IG, Park JO, Sohn TS, Reinhard C, Lee J, Kim S, Aggarwal A: Genomic landscape and genetic heterogeneity in gastric adenocarcinoma revealed by whole-genome sequencing. Nat Commun 2014;5:5477.

48 Frappier L: The Epstein-Barr virus EBNA1 protein. Scientifica (Cairo) 2012;2012: 438204.

49 Tempera I, Lieberman PM: Epigenetic regulation of EBV persistence and oncogenesis. Semin Cancer Biol 2014;26:22-29.

50 Fernandez AF, Rosales C, Lopez-Nieva P, Grana O, Ballestar E, Ropero S, Espada J, Melo SA, Lujambio A, Fraga MF, Pino I, Javierre B, Carmona FJ, Acquadro F, Steenbergen RD, Snijders PJ, Meijer CJ, Pineau P, Dejean A, Lloveras B, Capella G, Quer J, Buti M, Esteban JI, Allende H, Rodriguez-Frias F, Castellsague X, Minarovits J, Ponce J, Capello D, Gaidano G, Cigudosa JC, Gomez-Lopez G, Pisano DG, Valencia A, Piris MA, Bosch FX, Cahir-McFarland E, Kieff E, Esteller M: The dynamic DNA methylomes of double-stranded DNA viruses associated with human cancer. Genome Res 2009;19:438-451.
51 Chen C, Li D, Guo N: Regulation of cellular and viral protein expression by the EpsteinBarr virus transcriptional regulator Zta: implications for therapy of EBV associated tumors. Cancer Biol Ther 2009;8:987-995.

52 Kang GH, Lee S, Kim WH, Lee HW, Kim JC Rhyu MG, Ro JY: Epstein-Barr virus-positive gastric carcinoma demonstrates frequent $\mathrm{ab}$ errant methylation of multiple genes and constitutes $\mathrm{CpG}$ island methylator phenotypepositive gastric carcinoma. Am J Pathol 2002 160:787-794.

53 Osawa T, Chong JM, Sudo M, Sakuma K, Uozaki H, Shibahara J, Nagai H, Funata N, Fukayama M: Reduced expression and promoter methylation of p16 gene in Epstein-Barr virus-associated gastric carcinoma. Jpn J Cancer Res 2002;93:1195-1200.

54 Sakuma K, Chong JM, Sudo M, Ushiku T, Inoue Y, Shibahara J, Uozaki H, Nagai H, Fukayama M: High-density methylation of p14arf and p16ink4a in Epstein-Barr virusassociated gastric carcinoma. Int J Cancer 2004;112:273-278.

55 Sudo M, Chong JM, Sakuma K, Ushiku T, Uozaki H, Nagai H, Funata N, Matsumoto Y, Fukayama M: Promoter hypermethylation of Ecadherin and its abnormal expression in Epstein-Barr virus-associated gastric carcinoma. Int J Cancer 2004;109:194-199.

56 Chang MS, Uozaki H, Chong JM, Ushiku T, Sakuma K, Ishikawa S, Hino R, Barua RR, Iwasaki Y, Arai K, Fujii H, Nagai H, Fukayama M: CpG island methylation status in gastric carcinoma with and without infection of Epstein-Barr virus. Clin Cancer Res 2006;12: 2995-3002.

57 Chong JM, Sakuma K, Sudo M, Ushiku T, Uozaki H, Shibahara J, Nagai H, Funata N, Taniguchi $\mathrm{H}$, Aburatani $\mathrm{H}$, Fukayama M: Global and non-random CpG-island methylation in gastric carcinoma associated with EpsteinBarr virus. Cancer Sci 2003;94:76-80.

-58 Birdwell CE, Queen KJ, Kilgore PC, Rollyson P, Trutschl M, Cvek U, Scott RS: Genomewide DNA methylation as an epigenetic consequence of Epstein-Barr virus infection of immortalized keratinocytes. J Virol 2014;88: 11442-11458.

59 Hino R, Uozaki H, Murakami N, Ushiku T, Shinozaki A, Ishikawa S, Morikawa T, Nakaya T, Sakatani T, Takada K, Fukayama M: Activation of DNA methyltransferase 1 by EBV latent membrane protein $2 \mathrm{~A}$ leads to promoter hypermethylation of PTEN gene in gastric carcinoma. Cancer Res 2009;69:2766-2774.

60 Tao Q, Robertson KD: Stealth technology: how Epstein-Barr virus utilizes DNA methylation to cloak itself from immune detection. Clin Immunol 2003;109:53-63.

61 Bartel DP: MicroRNAs: genomics, biogenesis, mechanism, and function. Cell 2004;116: 281-297.

62 Barth S, Meister G, Grasser FA: EBV-encoded miRNAs. Biochim Biophys Acta 2011;1809: 631-640. 
-63 Kim DN, Chae HS, Oh ST, Kang JH, Park CH, Park WS, Takada K, Lee JM, Lee WK, Lee SK: Expression of viral microRNAs in EpsteinBarr virus-associated gastric carcinoma. J Virol 2007;81:1033-1036.

64 Marquitz AR, Mathur A, Chugh PE, Dittmer DP, Raab-Traub N: Expression profile of microRNAs in Epstein-Barr virus-infected AGS gastric carcinoma cells. J Virol 2014;88:13891393.

-65 Shinozaki-Ushiku A, Kunita A, Isogai M, Hibiya T, Ushiku T, Takada K, Fukayama M: Profiling of virus-encoded microRNAs in Epstein-Barr virus-associated gastric carcinoma and their roles in gastric carcinogenesis. J Virol 2015;89:5581-5591.

66 Cai LM, Lyu XM, Luo WR, Cui XF, Ye YF, Yuan CC, Peng QX, Wu DH, Liu TF, Wang E, Marincola FM, Yao KT, Fang WY, Cai HB, Li $\mathrm{X}$ : EBV-mir-BART7-3p promotes the EMT and metastasis of nasopharyngeal carcinoma cells by suppressing the tumor suppressor PTEN. Oncogene 2015;34:2156-2166.

- 67 Shinozaki A, Sakatani T, Ushiku T, Hino R, Isogai $\mathrm{M}$, Ishikawa $\mathrm{S}$, Uozaki $\mathrm{H}$, Takada $\mathrm{K}$, Fukayama M: Downregulation of microRNA-200 in EBV-associated gastric carcinoma. Cancer Res 2010;70:4719-4727.

-68 Pegtel DM, van de Garde MD, Middeldorp JM: Viral miRNAs exploiting the endosomalexosomal pathway for intercellular cross-talk and immune evasion. Biochim Biophys Acta 2011;1809:715-721.

-69 Pegtel DM, Cosmopoulos K, Thorley-Lawson DA, van Eijndhoven MA, Hopmans ES, Lindenberg JL, de Gruijl TD, Würdinger T, Middeldorp JM: Functional delivery of viral miRNAs via exosomes. Proc Natl Acad Sci USA 2010;107:6328-6333.

-70 Meckes DG Jr, Shair KH, Marquitz AR, Kung CP, Edwards RH, Raab-Traub N: Human tumor virus utilizes exosomes for intercellular communication. Proc Natl Acad Sci USA 2010;107:20370-20375.

-71 Gu J, Qian H, Shen L, Zhang X, Zhu W, Huang L, Yan Y, Mao F, Zhao C, Shi Y, Xu W: Gastric cancer exosomes trigger differentiation of umbilical cord derived mesenchymal stem cells to carcinoma-associated fibroblasts through TGF- $\beta /$ Smad pathway. PLoS One 2012; 7:e52465.

-72 Qu JL, Qu XJ, Zhao MF, Teng YE, Zhang Y, Hou KZ, Jiang YH, Yang XH, Liu YP: The role of cbl family of ubiquitin ligases in gastric cancer exosome-induced apoptosis of Jurkat T cells. Acta Oncol 2009;48:11731180 .

-73 Gourzones C, Gelin A, Bombik I, Klibi J, Verillaud B, Guigay J, Lang P, Temam S, Schneider V, Amiel C, Baconnais S, Jimenez AS, Busson P: Extra-cellular release and blood diffusion of BART viral micro-RNAs produced by EBV-infected nasopharyngeal carcinoma cells. Virol J 2010;7:271.

74 Wong AM, Kong KL, Tsang JW, Kwong DL, Guan XY: Profiling of Epstein-Barr virus-encoded microRNAs in nasopharyngeal carci- noma reveals potential biomarkers and oncomirs. Cancer 2012;118:698-710.

75 Mitchell PS, Parkin RK, Kroh EM, Fritz BR, Wyman SK, Pogosova-Agadjanyan EL, Peterson A, Noteboom J, O'Briant KC, Allen A, Lin DW, Urban N, Drescher CW, Knudsen BS, Stirewalt DL, Gentleman R, Vessella RL, Nelson PS, Martin DB, Tewari M: Circulating microRNAs as stable blood-based markers for cancer detection. Proc Natl Acad Sci USA 2008; 105:10513-10518.

76 Wilson BG, Roberts CW: SWI/SNF nucleosome remodellers and cancer. Nat Rev Cancer 2011;11:481-492.

-77 Wang K, Kan J, Yuen ST, Shi ST, Chu KM, Law S, Chan TL, Kan Z, Chan AS, Tsui WY, Lee SP, Ho SL, Chan AK, Cheng GH, Roberts PC, Rejto PA, Gibson NW, Pocalyko DJ, Mao $\mathrm{M}, \mathrm{Xu}$ J, Leung SY: Exome sequencing identifies frequent mutation of ARID1A in molecular subtypes of gastric cancer. Nat Genet 2011; 43:1219-1223.

-78 Zang ZJ, Cutcutache I, Poon SL, Zhang SL, McPherson JR, Tao J, Rajasegaran V, Heng HL, Deng N, Gan A, Lim KH, Ong CK, Huang D, Chin SY, Tan IB, Ng CC, Yu W, Wu Y, Lee M, Wu J, Poh D, Wan WK, Rha SY, So J, SaltoTellez M, Yeoh KG, Wong WK, Zhu YJ, Futreal PA, Pang B, Ruan Y, Hillmer AM, Bertrand D, Nagarajan N, Rozen S, Teh BT, Tan $\mathrm{P}$ : Exome sequencing of gastric adenocarcinoma identifies recurrent somatic mutations in cell adhesion and chromatin remodeling genes. Nat Genet 2012;44:570-574.

79 Wiegand KC, Shah SP, Al-Agha OM, Zhao Y, Tse K, Zeng T, Senz J, McConechy MK, Anglesio MS, Kalloger SE, Yang W, HeraviMoussavi A, Giuliany R, Chow C, Fee J, Zayed A, Prentice L, Melnyk N, Turashvili G, Delaney $\mathrm{AD}$, Madore J, Yip S, McPherson AW, Ha G, Bell L, Fereday S, Tam A, Galletta L, Tonin PN, Provencher D, Miller D, Jones SJ, Moore RA, Morin GB, Oloumi A, Boyd N, Aparicio SA, Shih IM, Mes-Masson AM, Bowtell DD, Hirst M, Gilks B, Marra MA, Huntsman DG: ARID1A mutations in endometriosis-associated ovarian carcinomas. N Engl J Med 2010;363:1532-1543.

80 Jones S, Wang TL, Shih IM, Mao TL, Nakayama K, Roden R, Glas R, Slamon D, Diaz LA, Vogelstein B, Kinzler KW, Velculescu VE, Papadopoulos N: Frequent mutations of chromatin remodeling gene ARID1A in ovarian clear cell carcinoma. Science 2010;330:228231.

81 Cancer Genome Atlas Network: Comprehensive molecular characterization of human colon and rectal cancer. Nature 2012;487:330337.

82 Totoki $\mathrm{Y}$, Tatsuno K, Covington KR, Ueda H, Creighton CJ, Kato M, Tsuji S, Donehower LA, Slagle BL, Nakamura H, Yamamoto S, Shinbrot E, Hama N, Lehmkuhl M, Hosoda F, Arai Y, Walker K, Dahdouli M, Gotoh K, Nagae G, Gingras MC, Muzny DM, Ojima H, Shimada K, Midorikawa Y, Goss JA, Cotton R, Hayashi A, Shibahara J, Ishikawa S, Gui- teau J, Tanaka M, Urushidate T, Ohashi S, Okada N, Doddapaneni H, Wang M, Zhu Y, Dinh H, Okusaka T, Kokudo N, Kosuge T, Takayama T, Fukayama M, Gibbs RA, Wheeler DA, Aburatani H, Shibata T: Trans-ancestry mutational landscape of hepatocellular carcinoma genomes. Nat Genet 2014;46: 1267-1273.

$\checkmark 83$ Fujimoto A, Totoki Y, Abe T, Boroevich KA Hosoda F, Nguyen HH, Aoki M, Hosono N, Kubo M, Miya F, Arai Y, Takahashi H, Shirakihara T, Nagasaki M, Shibuya T, Nakano K, Watanabe-Makino K, Tanaka H, Nakamura H, Kusuda J, Ojima H, Shimada K, Okusaka T, Ueno M, Shigekawa Y, Kawakami Y, Arihiro K, Ohdan H, Gotoh K, Ishikawa O, Ariizumi S, Yamamoto M, Yamada T, Chayama K, Kosuge T, Yamaue H, Kamatani N, Miyano S, Nakagama H, Nakamura Y, Tsunoda T, Shibata T, Nakagawa H: Whole-genome sequencing of liver cancers identifies etiological influences on mutation patterns and recurrent mutations in chromatin regulators. Nat Genet 2012;44:760-764.

84 Guichard C, Amaddeo G, Imbeaud S, Ladeiro Y, Pelletier L, Maad IB, Calderaro J, BioulacSage P, Letexier M, Degos F, Clement B, Balabaud C, Chevet E, Laurent A, Couchy G, Letouze E, Calvo F, Zucman-Rossi J: Integrated analysis of somatic mutations and focal copy-number changes identifies key genes and pathways in hepatocellular carcinoma. Nat Genet 2012;44:694-698.

-85 Huang J, Deng Q, Wang Q, Li KY, Dai JH, Li N, Zhu ZD, Zhou B, Liu XY, Liu RF, Fei QL, Chen H, Cai B, Xiao HS, Qin LX, Han ZG: Exome sequencing of hepatitis B virus-associated hepatocellular carcinoma. Nat Genet 2012;44:1117-1121.

86 Gui Y, Guo G, Huang Y, Hu X, Tang A, Gao S, Wu R, Chen C, Li X, Zhou L, He M, Li Z, Sun X, Jia W, Chen J, Yang S, Zhou F, Zhao X, Wan S, Ye R, Liang C, Liu Z, Huang P, Liu C, Jiang H, Wang Y, Zheng H, Sun L, Liu X, Jiang Z, Feng D, Wu S, Zou J, Zhang Z, Yang R, Zhao J, Xu C, Yin W, Guan Z, Ye J, Zhang H, Li J, Kristiansen K, Nickerson ML, Theodorescu D, Li Y, Zhang X, Li S, Wang J, Yang H, Cai Z: Frequent mutations of chromatin remodeling genes in transitional cell carcinoma of the bladder. Nat Genet 2011;43:875-878.

87 Strauss BS: Frameshift mutation, microsatellites and mismatch repair. Mutat Res 1999; 437:195-203.

88 Fleisher AS, Esteller M, Wang S, Tamura G, Suzuki H, Yin J, Zou TT, Abraham JM, Kong D, Smolinski KN, Shi YQ, Rhyu MG, Powell SM, James SP, Wilson KT, Herman JG, Meltzer SJ: Hypermethylation of the hMLH1 gene promoter in human gastric cancers with microsatellite instability. Cancer Res 1999;59: 1090-1095

89 Kang GH, Shim YH, Ro JY: Correlation of methylation of the hMLH1 promoter with lack of expression of hMLH1 in sporadic gastric carcinomas with replication error. Lab Invest 1999;79:903-909. 
90 Leung SY, Yuen ST, Chung LP, Chu KM, Chan AS, Ho JC: hMLH1 promoter methylation and lack of hMLH1 expression in sporadic gastric carcinomas with high-frequency microsatellite instability. Cancer Res 1999;59:159-164.

91 Shimizu T, Marusawa H, Matsumoto Y, Inuzuka T, Ikeda A, Fujii Y, Minamiguchi S, Miyamoto S, Kou T, Sakai Y, Crabtree JE, Chiba T: Accumulation of somatic mutations in TP53 in gastric epithelium with Helicobacter pylori infection. Gastroenterology 2014;147: 407-417.e403.

$\$ 2$ Day L, Chau CM, Nebozhyn M, Rennekamp AJ, Showe M, Lieberman PM: Chromatin profiling of Epstein-Barr virus latency control region. J Virol 2007;81:6389-6401.

93 Chang LK, Liu ST: Activation of the BRLF1 promoter and lytic cycle of Epstein-Barr virus by histone acetylation. Nucleic Acids Res 2000;28:3918-3925.

$\$ 94$ Samuels Y, Waldman T: Oncogenic mutations of PIK3CA in human cancers. Curr Top Microbiol Immunol 2010;347:21-41.

$\$ 95$ Samuels Y, Velculescu VE: Oncogenic mutations of PIK3CA in human cancers. Cell cycle 2004;3:1221-1224.

$\$ 6$ Gymnopoulos M, Elsliger MA, Vogt PK: Rare cancer-specific mutations in PIK3CA show gain of function. Proc Natl Acad Sci USA 2007;104:5569-5574.

97 Chen J: Roles of the PIK3CA pathway in Epstein-Barr virus-induced cancers and therapeutic implications. World J Virol 2012;1: 154-161.

\$8 Yuen JW, Chung GT, Lun SW, Cheung CC, To KF, Lo KW: Epigenetic inactivation of inositol polyphosphate 4-phosphatase B (INPP4B), a regulator of PI3K/Akt signaling pathway in EBV-associated nasopharyngeal carcinoma. PLoS One 2014;9:e105163.

99 Tsang CM, Zhang G, Seto E, Takada K, Deng W, Yip YL, Man C, Hau PM, Chen H, Cao Y, Lo KW, Middeldorp JM, Cheung AL, Tsao SW: Epstein-Barr virus infection in immortalized nasopharyngeal epithelial cells: Regulation of infection and phenotypic characterization. Int J Cancer 2010;127: 1570-1583.

100 Wiegand KC, Shah SP, Al-Agha OM, Zhao Y, Tse K, Zeng T, Senz J, McConechy MK, Anglesio MS, Kalloger SE, Yang W, HeraviMoussavi A, Giuliany R, Chow C, Fee J, Zayed A, Prentice L, Melnyk N, Turashvili G, Delaney AD, Madore J, Yip S, McPherson AW, Ha G, Bell L, Fereday S, Tam A, Galletta L, Tonin PN, Provencher D, Miller D, Jones SJ, Moore RA, Morin GB, Oloumi A, Boyd N, Aparicio SA, Shih IM, Mes-Masson AM, Bowtell DD, Hirst M, Gilks B, Marra MA, Huntsman DG: ARID1A mutations in endometriosis-associated ovarian carcinomas. N Engl J Med 2010;363:1532-1543.

101 Yamamoto S, Tsuda H, Takano M, Tamai S, Matsubara O: Loss of ARID1A protein ex- pression occurs as an early event in ovarian clear-cell carcinoma development and frequently coexists with PIK3CA mutations. Mod Pathol 2012;25:615-624.

102 Chandler RL, Damrauer JS, Raab JR, Schisler JC, Wilkerson MD, Didion JP, Starmer J, Serber D, Yee D, Xiong J, Darr DB, PardoManuel de Villena F, Kim WY, Magnuson T: Coexistent ARID1A-PIK3CA mutations promote ovarian clear-cell tumorigenesis through pro-tumorigenic inflammatory cytokine signalling. Nat Commun 2015;6: 6118.

103 Gao J, Aksoy BA, Dogrusoz U, Dresdner G, Gross B, Sumer SO, Sun Y, Jacobsen A, Sinha R, Larsson E, Cerami E, Sander C, Schultz N: Integrative analysis of complex cancer genomics and clinical profiles using the cBioPortal. Sci Signal 2013;6:pl1.

104 Cerami E, Gao J, Dogrusoz U, Gross BE, Sumer SO, Aksoy BA, Jacobsen A, Byrne CJ, Heuer ML, Larsson E, Antipin Y, Reva B, Goldberg AP, Sander C, Schultz N: The cBio cancer genomics portal: an open platform for exploring multidimensional cancer genomics data. Cancer Discov 2012;2:401404.

105 Huynh KD, Fischle W, Verdin E, Bardwell VJ: BCoR, a novel corepressor involved in BCL-6 repression. Genes Dev 2000;14: 1810-1823.

106 Grossmann V, Tiacci E, Holmes AB, Kohlmann A, Martelli MP, Kern W, SpanholRosseto A, Klein HU, Dugas M, Schindela S, Trifonov V, Schnittger S, Haferlach C, Bassan R, Wells VA, Spinelli O, Chan J, Rossi R, Baldoni S, De Carolis L, Goetze K, Serve H, Peceny R, Kreuzer KA, Oruzio D, Specchia G, Di Raimondo F, Fabbiano F, Sborgia M, Liso A, Farinelli L, Rambaldi A, Pasqualucci L, Rabadan R, Haferlach T, Falini B: Wholeexome sequencing identifies somatic mutations of BCOR in acute myeloid leukemia with normal karyotype. Blood 2011;118: 6153-6163.

107 Damm F, Chesnais V, Nagata Y, Yoshida K, Scourzic L, Okuno Y, Itzykson R, Sanada M, Shiraishi Y, Gelsi-Boyer V, Renneville A, Miyano S, Mori H, Shih LY, Park S, Dreyfus F, Guerci-Bresler A, Solary E, Rose C, Cheze S, Prebet T, Vey N, Legentil M, Duffourd Y, de Botton S, Preudhomme C, Birnbaum D, Bernard OA, Ogawa S, Fontenay M, Kosmider O: BCOR and BCORL1 mutations in myelodysplastic syndromes and related disorders. Blood 2013;122:3169-3177.

108 Pugh TJ, Weeraratne SD, Archer TC, Pomeranz Krummel DA, Auclair D, Bochicchio J, Carneiro MO, Carter SL, Cibulskis K, Erlich RL, Greulich H, Lawrence MS, Lennon NJ, McKenna A, Meldrim J, Ramos AH, Ross MG, Russ C, Shefler E, Sivachenko A, Sogoloff B, Stojanov P, Tamayo P, Mesirov JP, Amani V, Teider N, Sengupta S, Francois JP, Northcott PA, Taylor MD, Yu F, Crab- tree GR, Kautzman AG, Gabriel SB, Getz G, Jager N, Jones DT, Lichter P, Pfister SM, Roberts TM, Meyerson M, Pomeroy SL, Cho YJ: Medulloblastoma exome sequencing uncovers subtype-specific somatic mutations. Nature 2012;488:106-110.

109 Tiberi L, Bonnefont J, van den Ameele J, Le Bon SD, Herpoel A, Bilheu A, Baron BW, Vanderhaeghen P: A BCL6/BCOR/SIRT1 complex triggers neurogenesis and suppresses medulloblastoma by repressing sonic hedgehog signaling. Cancer Cell 2014;26: 797-812.

110 Pedoeem A, Azoulay-Alfaguter I, Strazza M, Silverman GJ, Mor A: Programmed death-1 pathway in cancer and autoimmunity. Clin Immunol 2014;153:145-152.

111 Thompson RH, Dong H, Kwon ED: Implications of B7-H1 expression in clear cell carcinoma of the kidney for prognostication and therapy. Clin Cancer Res 2007;13:709s$715 \mathrm{~s}$.

112 Wu C, Zhu Y, Jiang J, Zhao J, Zhang XG, Xu $\mathrm{N}$ : Immunohistochemical localization of programmed death-1 ligand-1 (PD-L1) in gastric carcinoma and its clinical significance. Acta Histochem 2006;108:19-24.

113 Hou J, Yu Z, Xiang R, Li C, Wang L, Chen S, Li Q, Chen M, Wang L: Correlation between infiltration of $\mathrm{FOXP} 3+$ regulatory $\mathrm{T}$ cells and expression of $\mathrm{B} 7-\mathrm{H} 1$ in the tumor tissues of gastric cancer. Exp Mol Pathol 2014; 96:284-291.

114 Herbst RS, Soria JC, Kowanetz M, Fine GD, Hamid O, Gordon MS, Sosman JA, McDermott DF, Powderly JD, Gettinger SN, Kohrt HE, Horn L, Lawrence DP, Rost S, Leabman M, Xiao Y, Mokatrin A, Koeppen H, Hegde PS, Mellman I, Chen DS, Hodi FS: Predictive correlates of response to the anti-PD-L1 antibody MPDL3280A in cancer patients. Nature 2014;515:563-567.

115 Powles T, Eder JP, Fine GD, Braiteh FS, Loriot Y, Cruz C, Bellmunt J, Burris HA, Petrylak DP, Teng SL, Shen X, Boyd Z, Hegde PS, Chen DS, Vogelzang NJ: MPDL3280A (anti-PD-L1) treatment leads to clinical activity in metastatic bladder cancer. Nature 2014;515:558-562.

116 Brahmer JR, Tykodi SS, Chow LQ, Hwu WJ, Topalian SL, Hwu P, Drake CG, Camacho LH, Kauh J, Odunsi K, Pitot HC, Hamid O, Bhatia S, Martins R, Eaton K, Chen S, Salay TM, Alaparthy S, Grosso JF, Korman AJ, Parker SM, Agrawal S, Goldberg SM, Pardoll DM, Gupta A, Wigginton JM: Safety and activity of anti-PD-L1 antibody in patients with advanced cancer. N Engl J Med 2012; 366:2455-2465.

117 Nagy N, Klein G, Klein E: To the genesis of Burkitt lymphoma: regulation of apoptosis by EBNA-1 and SAP may determine the fate of Ig-myc translocation carrying $B$ lymphocytes. Semin Cancer Biol 2009;19: 407-410. 